\title{
Étude de l'affixation dérivationnelle par traitement automatique du lexique juridique canadien
}

Jean-Louis Duchet et Olivier Chaulet

\section{OpenEdition}

Journals

Édition électronique

URL : http://journals.openedition.org/asp/1070

DOI : 10.4000/asp. 1070

ISBN : 978-2-8218-0396-1

ISSN : 2108-6354

\section{Éditeur}

Groupe d'étude et de recherche en anglais de spécialité

Édition imprimée

Date de publication : 1 mars 2004

Pagination : 81-98

ISSN : 1246-8185

Référence électronique

Jean-Louis Duchet et Olivier Chaulet, «Étude de l'affixation dérivationnelle par traitement automatique du lexique juridique canadien », ASp [En ligne], 43-44 | 2004, mis en ligne le 29 mars 2010, consulté le 02 mai 2019. URL : http://journals.openedition.org/asp/1070 ; DOI : 10.4000/asp.1070

Ce document a été généré automatiquement le 2 mai 2019.

Tous droits réservés 


\title{
Étude de l'affixation dérivationnelle par traitement automatique du lexique juridique canadien
}

\author{
Jean-Louis Duchet et Olivier Chaulet
}

\section{Description du corpus}

Nous avons constitué un corpus recueilli sur le web qui comporte les décisions de la Cour suprême du Canada sur deux années, 2000 et 2001 ; chaque décision de la Cour est rédigée en français et en anglais. Le corpus de près de trois millions de mots vise à permettre l'étude contrastive du discours juridique dans les deux langues. Nous ne l'exploiterons ici qu'à des fins lexicologiques limitées au vocabulaire spécialisé de l'anglais. Un extrait de notre corpus figure au tableau 1.

Tableau 1. Extrait de corpus

\begin{tabular}{|l|l|}
\hline anglais & français \\
\hline $\begin{array}{l}\text { 1. The accused was convicted of sexual } \\
\text { assault and invitation to sexual touching in } \\
\text { relation to incidents with his step- } \\
\text { granddaughter. }\end{array}$ & $\begin{array}{l}\text { 1. L'accusé a été déclaré coupable d'agression } \\
\text { sexuelle et d'incitation à des contacts sexuels sur } \\
\text { sa petite-fille par remariage. }\end{array}$ \\
\hline $\begin{array}{l}\text { 2. The offences were committed between } \\
\begin{array}{l}1990 \text { and } 1994 \text { and, at the time, the victim } \\
\text { was between } 5 \text { and } 8 \text { and the accused was } \\
\text { between } 46 \text { and } 50 \text { years old. }\end{array}\end{array}$ & $\begin{array}{l}\text { Lorsque les infractions ont commencé, la victime } \\
\text { avait } 5 \text { ans et l'accusé en avait } 46, \text { et lorsqu'elles } \\
\text { ont cessé la victime avait } 8 \text { ans et l'accusé } 50 \text { ans. }\end{array}$ \\
\hline
\end{tabular}




\begin{tabular}{|c|c|}
\hline $\begin{array}{l}\text { 3. The conditional sentencing regime came } \\
\text { into force after the accused was sentenced. } \\
\text { The Court of Appeal allowed the accused's } \\
\text { sentence appeal and substituted a nine- } \\
\text { month conditional sentence. }\end{array}$ & $\begin{array}{l}\text { 3. Le juge du procès a condamné l'accusé à neuf } \\
\text { mois d'emprisonnement. Le régime d'octroi du } \\
\text { sursis à l'emprisonnement est entré en vigueur } \\
\text { après la détermination de la peine de l'accusé. }\end{array}$ \\
\hline 4. Held: The appeal should be allowed. & 4. Arrêt : Le pourvoi est accueilli. \\
\hline $\begin{array}{l}\text { 5. Per Lamer C.J. and Iacobucci, Major and } \\
\text { Binnie JJ.: For the reasons outlined in R. v. } \\
\text { R.A.R., [2000] } 1 \text { S.C.R. 163, } 2000 \text { SCC } 8 \text {, the } \\
\text { accused was entitled to the benefit of the } \\
\text { conditional sentencing regime on appeal, } \\
\text { and the Court of Appeal could re-sentence } \\
\text { him. }\end{array}$ & $\begin{array}{l}\text { 5. Le juge en chef Lamer et les juges Iacobucci, } \\
\text { Major et Binnie: Pour les raisons exposées dans R. } \\
\text { c. R.A.R., [2000] } 1 \text { R.C.S. } 163,2000 \text { CSC } 8, \text { l'accusé } \\
\text { avait droit, en appel, au bénéfice de l'application } \\
\text { du régime d'octroi du sursis, et la Cour d'appel } \\
\text { pouvait procéder à nouveau à la détermination de } \\
\text { sa peine. }\end{array}$ \\
\hline $\begin{array}{l}\text { 6. Notwithstanding the deference to which } \\
\text { sentencing decisions by a court of appeal } \\
\text { are entitled, this Court should intervene in } \\
\text { this case and restore the trial judge's } \\
\text { original sentence. }\end{array}$ & $\begin{array}{l}\text { 6. Malgré la retenue dont elle doit faire preuve à } \\
\text { l'égard des peines infligées par les cours d'appel, } \\
\text { notre Cour devrait intervenir en l'espèce et } \\
\text { rétablir la peine initiale infligée par le juge du } \\
\text { procès. }\end{array}$ \\
\hline
\end{tabular}

2 Nous avons enrichi le corpus d'un balisage XML pour faciliter les références aux cent trente décisions que nous avons compilées et avons recherché par concordancier les occurrences des termes faisant référence aux partenaires d'une relation juridique, marquée par les suffixes -ee et -or. Ces termes forment un mini-lexique dont les propriétés dérivationnelles et les structures argumentales dans lesquelles elles entrent méritent d'être étudiées de près pour discerner les raffinements morphologiques et sémantiques qui se cachent derrière la simplicité formelle d'une opposition suffixale.

\section{Sémantique et morphologie lexicale}

3 Notre travail d'analyse se situe à la lisière de la linguistique générale et de la lexicologie appliquée à un domaine spécialisé. Il convient donc en premier lieu de mener une réflexion générale sur la valeur de base des suffixes -ee et -or et de déterminer rapidement leur forme schématique : comment ceux-ci fonctionnent-ils habituellement et comment se positionnent-ils dans la langue commune? Par ailleurs, à l'instar des mots, les suffixes -ee et -or peuvent être polysémiques : quels sens ceux-ci recouvrent-ils?

\footnotetext{
偕 -er / -or

- added to some verbs to form nouns which refer to people or things that do that particular activity: singer, swimmer, actor, vendor

- added to the names of particular subjects to form nouns which refer to people who have knowledge about or are studying that subject: philosopher, astronomer

- added to the names of particular places to form nouns referring to people who come from those places: Londoner, Northerner

- added to nouns or adjectives to form nouns referring to people who are connected or involved with that particular thing: pensioner, first graders - added to nouns to form nouns or adjectives referring to people or things
} 
which have those particular characteristics: double-decker, big-spender.

(Cambridge Advanced Learner's Dictionary [CALD])

瞇 -ee

- added to a verb to form a noun which refers to the person to whom the action of the verb is being done: employee, interviewee, payee

- added to an adjective, noun or verb to refer to a person who is in that condition or state : refugee, escapee. [CALD]

Il ne fait aucun doute que le suffixe agentif -or a une coloration plutôt spécialisée du fait qu'il est distribué avec des bases d'origine latine. On trouve en effet de nombreux termes techniques qui comportent le suffixe -or (ex. adjudicator). En revanche, plusieurs mots de la langue banale, quoiqu'en petit nombre, l'utilisent également: par exemple actor ou inventor. On trouve néanmoins plus fréquemment le suffixe -er pour marquer l'agentivité (cf. singer, swimmer, dishwasher où -er est distribué avec des bases d'origine germanique). Il s'agit pour nous de nous intéresser au degré de technicité d'un terme : les suffixes -er et -or sont-ils concurrents? Un terme comme absentee est-il perçu comme spécialisé par un locuteur anglophone? Nous constatons que le Robert \& Collins senior propose des traductions qui vont du suffixé en "-iste » (absentéiste) à la forme périphrastique " celui qui est absent », en passant par le substantif « absent ».

5 Nous procèderons à l'analyse des items extraits du corpus juridique du point de vue de la morphologie lexicale (affixes dérivationnels), de la sémantique lexicale et des relations prédicatives sous-jacentes que nous pourrons mettre en évidence. Notre objectif est d'étudier les différents phénomènes donnant à un terme juridique son caractère spécialisé ou bien au contraire le conduisant à la banalisation (concept culturel popularisé). Il s'agit de mettre au jour les procédés lexicaux variés qui régissent le degré de spécialisation ou de banalisation d'un mot. Nous examinerons systématiquement les suffixés en -ee et en -or (opposition -ee / -or spécifique de la langue de spécialité), en -ent et -ant tant du point de vue de la productivité lexicogénétique (morphologie lexicale) que du point de vue des relations prédicatives (structures argumentales) qui en sont la source (sémantique lexicale). S'agissant de la langue de spécialité, nous avançons l'hypothèse que la productivité lexicale de certaines dérivations n'est attestée que dans la langue de spécialité, qui acquiert par là un fonctionnement linguistique propre. À la lumière de cette hypothèse, nous analyserons aussi les suffixations en -er et en -or.

\section{Paires lexicales symétriques et asymétriques}

6 Nous utilisons l'expression " paire symétrique » pour désigner deux mots construits sur le même radical et dont il existe un dérivé en -ee et un dérivé en -or ou -er du type employee / employer.

\subsection{Les paires lexicales symétriques : harmonisation lexicographique et harmonisation phonologique}

\subsubsection{Mortgagee et mortgagor}

7 Nous avons pu relever dans le corpus un certain nombre de paires symétriques, parmi lesquelles figurent plusieurs occurrences de mortgagee et de mortgagor. L'étude de cette 
paire est révélatrice de quelques phénomènes linguistiques inhérents à la langue de spécialité.

Définitions des items lexicaux :

mortgagee [,mo:gI'dzi:] noun [C] SPECIALISED

- a bank or similar organization which gives mortgages to people, especially so that they can buy a house or apartment. [CALD]

- the person to whom property is mortgaged, the lender of the mortgage debt. (Osborn's Concise Law Dictionary [ocLD])

- person or company which lends money for someone to buy a property and takes a mortgage of the property as security. (Dictionary of Law [CoLLin])

- the person who accepts a mortgage (-> mortgage holder). ([FREE])

Extrait du corpus :

But in this case there is no difficulty in separating the interest of the mortgagee from that of the owner; and if the mortgagee should recover on the policy, the owner will not be advantaged, as the insurers will be subrogated as against him to the rights of the mortgagee.

Scott v. Wawanesa mutual insurance co., 1989.

Mortgagor [,mo:gr'dzo:]

- the person who mortgages his property as security for the mortgage debt; the borrower. [ocLD]

- person who borrows money giving a property as security. [CoLLIN]

- the party borrowing money from a bank or other lending agency, who secures the loan with property the party owns in whole or in part. (Law Dictionary [BARRON])

Extrait du corpus :

Shortly before the mortgage was to mature, the mortgagor and the bank executed an agreement which renewed the mortgage for a further threeyear term at a yearly interest rate of 13 percent.

[...] the agreement was signed only by the mortgagor. The mortgagor defaulted on the mortgage, and the bank obtained a summary judgment against the mortgagor and the guarantors for the principal owing under the mortgage with interest at 13 percent per annum.

Manulife Bank of Canada v. Conlin.

mortgage ['mo:gidz] noun [C]

- an agreement which allows you to borrow money from a bank or similar organization, especially in order to buy a house or apartment, or the amount of money itself.

ex. : They took out a $£ 40000$ mortgage (They borrowed $£ 40000$ ) to buy the house - a monthly mortgage payment. [CALD]

8 En ce qui concerne la paire mortgagee et mortgagor, nous constatons d'emblée une irrégularité d'ordre phonologique : mortgagee obéit à la règle ${ }^{1}$ des mots comportant la terminaison contraignante -ee; l'accent principal tombe par conséquent sur la dernière syllabe et l'accent secondaire sur la première: [,mo:gi'dzi:]. Et le mot mortgagor, qui, quant à lui, comporte simplement le suffixe agentif non-contraignant -or, reçoit néanmoins aussi l'accent principal sur la dernière syllabe, alors que la règle (-or étant une terminaison accentuellement neutre) laisse attendre l'accent sur la première syllabe comme dans mortgage.

9 Ce processus d'harmonisation phonologique, qui impose l'isomorphisme accentuel des deux termes de la paire, aboutit à l'irrégularité d'un schéma accentuel $/ 201{ }^{2}:$ [,mo:gI'd子 
๑:]. Il y a une entorse à la règle phonologique et l'isomorphisme l'emporte sur celle-ci. La langue de spécialité procure les rares occasions où les terminaisons neutres peuvent devenir contraignantes et où la cohérence phonologie / lexicologie n'est pas toujours respectée. L'accentuation de -or rappelle, en un sens, le phénomène de composition où chaque élément est accentué.

De plus dans mortgagor, par un processus de motivation dérivationnelle interne à la langue de spécialité qui semble exiger un isomorphisme strict (accentuel et graphématique), l'orthographe viole une contrainte de la langue commune qui empêche normalement de prononcer [d]] un $\langle g\rangle$ placé devant la voyelle d'arrière $\langle 0\rangle$. On prononce [dzo:] au mépris de la règle graphophonématique ${ }^{3}$. Mais ici l'important est d'identifier mortgag-. Ce mot est en fait soumis à une fluctuation d'usage relativement forte, car la graphie mortgageor est également attestée, manifestant une variation qui est contraire au principe d'isomorphisme strict et qui montre une adaptation de la graphie aux règles habituelles. Ces variations orthographiques sont le résultat d'un conflit ${ }^{4}$ entre les règles de correspondances graphophonématiques générales de la langue commune et l'harmonisation du lexique spécialisé recherchée par ses utilisateurs. Nous sommes face à un gradient et l'usage favorise tantôt une forme, tantôt une autre.

11 Nous pouvons postuler, suite à l'étude de cet exemple, que l'accentuation d'un terme sur le suffixe agentif -or, habituellement neutre, a lieu lorsqu'il existe une forme dérivationnelle en -ee du même radical qui est son complémentaire sémantique. La langue de spécialité adopte un seul et unique schéma accentuel au prix d'une irrégularité phonologique, de manière à marquer par une symétrie phonologique une opposition conceptuelle claire entre deux termes que l'on retrouve au sein d'un même univers de référence ou d'une même discipline. Ce qui est en jeu dans mortgagee et mortgagor, c'est bien d'établir un contraste net entre les deux partenaires du procès dans le contexte discursif juridique.

12 Par ailleurs, la relation prédicative sous-jacente à la paire mortgagee / mortgagor est relativement complexe puisqu'il s'agit d'un verbe trivalent ${ }^{5}$. Celle-ci implique en effet trois participants : deux animés humains et un objet. Pour ce qui est de l'opposition lexicale à deux termes qui nous occupe, la relation ne concerne que les animés. Quel rapport existe-t-il entre les deux animés? Il y a un agent, the mortgagor (the borrower) et un bénéficiaire, the mortgagee (the lender), auxquels il sera fait référence par les deux suffixes, le bien hypothéqué étant ici le patient auquel il sera fait référence par la désinence participiale ${ }^{6}$. Nous pouvons également noter que la relation, dans le cadre du processus de mortgaging, est réversible. Il est possible de renverser la relation et d'inverser les rôles thématiques: l'agent (celui qui hypothèque son bien immobilier) devient bénéficiaire (de l'argent qui lui est prêté) et le bénéficiaire (du bien hypothéqué) devient alors agent (c'est lui qui prête de l'argent). C'est le principe même de la contrepartie du droit du contrat ${ }^{7}$.

13 Nous remarquons également que la relation prédicative tourne autour d'un verbe attesté : to mortgage.

\author{
to mortgage ['mo:gid\}] verb [T] \\ ex. : The house was mortgaged up to the hilt (The full value of the house had \\ been borrowed). [CALD]
}

14 Ce verbe est, semble-t-il, dans la grande majorité des cas, utilisé à la forme passive avec pour sujet le patient: property is morgaged. L'étude statistique montre en effet que to 
mortgage est le plus souvent utilisé à la forme passive et on remarque l'utilisation massive des noms de la paire symétrique mortgagee / mortgagor pour faire référence à ce processus juridique.

Notons qu'en termes d'équivalence lexicale nous avons également relevé des occurrences de hypothecary debtor et hypothecary creditor pour référer respectivement à mortgagor et à mortgagee.

\begin{abstract}
hypothecary debtor / hypothecary creditor $\rightarrow$ mortgagor / mortgagee Does the taking-in-payment of the rights of an Emphyteutic Lessee by an hypothecary creditor of such rights, create a [...] Sun Life Assurance Co. of Canada c. 137578 Canada inc, 2000. In that case, the insured hypothecary debtor (mortgagor) made misrepresentations in his application for property insurance. The policy contained the Standard Mortgage Clause. The property was destroyed by fire and the insurers refused to pay the hypothecary creditor (mortgagee), alleging that the policy was void $a b$ initio as a result of the misrepresentations by the debtor when the policy was purchased. The mortgagor did not disclose the occurrence of criminal fires on the insured premises and the refusal by the previous insurer to continue to insure the property. The mortgagee relied on the Standard Mortgage Clause and brought an action against the insurers. Healy v. Pilot Insurance Co., 2003.
\end{abstract}

\title{
3.1.2. Covenantee et covenantor
}

Une paire du même genre se trouve avec covenantee / covenantor. Le contraste entre les deux items lexicaux partageant le même radical se manifeste là aussi dans l'accentuation :

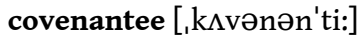

- one who receives the covenant, or for whom it is made. [BARRON]

Extrait du corpus :

Where an instrument contains a covenant registrable under this section, the covenant is binding on the covenantee and his successors in title, notwithstanding that the instrument or other disposition has not been signed by the covenantee.

[...] the covenant is binding on the covenantee and his successors in title, notwithstanding that the instrument or other disposition has not been signed by the covenantee.

Pacific National Investments Ltd. v. Victoria (City), 2000.

covenantor [,kAvənən'to:]

- one who makes a covenant [BARRON]

Extrait du corpus :

Section 215(3) was clearly intended to provide that a covenant was still binding on the covenantor, even when the covenantee had not signed it.

[...] in favour of the Crown or a Crown corporation or agency or of a municipality or a regional district, in this section referred to as the "covenantee", may be registered as a charge against the title to that land and is enforceable against the covenantor and his successors in title, even if the covenant is not annexed to land owned by the covenantee.

[...] in fine by contrast, describes how the covenant is "enforceable against the covenantor". And, indeed, British Columbia later corrected the words of the s. 215(3) on which PNI relies, by amending them in 1989 to read "binding 
on the covenantor": Land Title Amendment Act, 1989, S.B.C. 1989, c. 69, s. 22.

Pacific National Investments Ltd. v. Victoria (City), 2000.

17 Le radical, quoique de manière moins évidente que pour mortgage, est aussi celui d'un verbe qui exprime une relation prédicative dont les deux dérivés en -ee et en -or désignent des partenaires. Nous trouvons dans notre corpus l'exemple suivant avec covenant (verbe) :

Where a debtor covenants in a deed to pay a debt antecedently based in simple contract, the right to sue in debt merges in the right to sue on the covenant and is extinguished in law.

R. v. Catcheway, SCC 33. File No 27161, 2000: June 15.

\subsubsection{Assignee et assignor}

Une autre paire symétrique fondée sur un radical verbal, assign, est la suivante : assignor / assignee.

assignor [,æsI'nO:] noun [C] (Oxford English Dictionary [OED])

- person who assigns something to someone. (Dictionary of Law [CoLLIN])

Extrait du corpus :

The order affects the insolvent assignee and its creditors, including the original tenant and assignor of the leases, but does not reach to the landlords. I would dismiss the appeal.

First, an assignor is no different from other alternative debtors, none of which is excused under the Act.

Crystalline Investments Ltd. v. Domgroup Ltd.

Further, an absolute assignment of book debts makes those book debts the property of the assignee, and they remain the property of the assignee until the assignor actually exercises his equitable right to redeem. In determining whether the book debts, once assigned, are the "property" of the assignor or of the assignee, the court must interpret the word in its plain and ordinary sense.

Alberta (Treasury Branches) v. M.N.R.; Toronto-Dominion Bank v. M.N.R.

assignee [,æsI' nI:] [OED] / [,æsaI'nI:] noun [C] (Longman Pronunciation Dictionary [LPD]) : l'inaccentuée en seconde syllabe est diphtonguée dans LPD : il y a variation.

- person who receives something which has been assigned. [CoLLIN]

Extrait du corpus :

[...] the mere possibility that the original tenant may have a right of indemnity against his insolvent assignee and is able to make a claim to participate in the proposal proceedings as an unsecured creditor is not inconsistent with the Bankruptcy and Insolvency Act.

The question is whether the terms of the reorganization by the insolvent assignee through its trustee where it purported to repudiate the leases under s. 65.2 of the Act affect the obligations between the landlords and the original tenant.

This would mean that directors who guarantee their company's obligations would not be liable if their own company became insolvent whilst tenant, but they would be liable if an assignee from their company encountered financial difficulties whilst tenant.

Crystalline Investments Ltd. v. Domgroup Ltd. 

phonétiquement inaccentué habituellement imputable à la terminaison -or. Quant à la variation qui affecte la voyelle de la syllabe médiane inaccentuée de [ıæsı'ni:], elle semble attester de la tendance contemporaine, commune dans la langue spécialisée, à marquer par la phonologie les solidarités dérivationnelles : c'est en effet le LPD, plus récent, qui atteste un [aI] comme dans assign [ə'saIn], tandis que la prononciation relevée par l'OED est plus anciennement attestée. De plus, nous remarquons le jeu d'alternance accentuelle avec les trisyllabes du type assignee et assignor : l'accent principal est attiré sur la dernière syllabe, ce qui impose un accent secondaire sur la première. Du coup, on a [æ] au lieu d'une voyelle phonologiquement inaccentuée réduite à schwa [ə].

\subsubsection{Payee, payor (et payer)}

21 Une troisième paire symétrique présente dans le corpus mérite une analyse détaillée, il s'agit de payee et de payor.

Définitions des items lexicaux :

payee [peI'i:] noun [C] SPECIALIZED (law)

- a person whose money is paid to or should be paid to. [CALD]

- the person to whom a bill of exchange is payable. [OCLD]

Extrait du corpus :

In Brissette Estate v. Westbury Life Insurance Co., [1992] 3 S.C.R. 87, Sopinka J. held that "a person should not be allowed to insure against his or her own criminal act irrespective of the ultimate payee of the proceeds" (p. 94).

Oldfield v. Transamerica Life Insurance Co. of Canada.

[...] two questions: (a) whether, despite the acceptor's lack of knowledge or intention that the payee was named in the bill by way of pretense only, the payee, although an existing person, was nevertheless fictitious within the meaning of the Bills of Exchange Act and the bills therefore to be treated as payable to bearer, making an endorsement by the payee unnecessary; and (b) whether, in any event, the acceptor was estopped by his conduct from setting up the forgery of the payee's endorsement against the bank.

Canadian Pacific Hotels Ltd. v. Bank of Montreal, 1987.

payor [peI'o:] SPECIALIZED (law)

- a person who pays money for something. [CALD]

Extrait du corpus :

[...] to some extent, it mirrors s. 60(b) ITA, which permits the payor of such sums to deduct these sums from taxable income.

By virtue of s. 60(b), this benefit is initially uniquely available to the payor of such support, who is the non-custodial parent.

The second dynamic is the "upside-down subsidy". The value of the tax deduction of child support to the payor depends upon the payor's marginal tax rate. Similarly, the cost of inclusion in taxable income of child support depends upon the recipient's marginal tax rate. Where the marginal tax rate of the payor is higher than the marginal tax rate of the recipient, then net tax savings ensue to the couple.

Thibaudeau v. Canada, 1995. 
payer ['peIə] noun

1. good/bad payer : a person who usually pays on time/late.

2. used as a combining form: a taxpayer. [CALD] l'expression est incomplète soit parce qu'un seul terme est attesté ou bien parce que l'un des deux est très rarement attesté.

\subsubsection{Debtee et debtor}

Outre les exemples de paires symétriques que nous avons pu relever dans le corpus, certains radicaux possèdent un dérivé en -or mais ne possèdent a priori pas de dérivé en -ee. C'est le cas de debtor, qui n'est pas dérivé d'un verbe mais qui est formé sur un nom abstrait d'origine française dont le prédicat sous-jacent est une périphrase de type have + N. Il s'agit donc de suffixation pseudo-verbale (à la différence de mots comme assignor / assignee qui dérivent d'un véritable verbe). Debtor, privé d'un correspondant en -ee, est donc accentué sur la première syllabe et non sur le suffixe puisqu'il n'y a ici nulle nécessité de le contraster avec * debtee.

Aussi douteuse soit-elle, la dérivation *debtee est tout de même attestée. Nous l'avons rencontrée dans l'OED et dans FREE, mais ni dans LPD, ni dans CALD, ni même dans l'ouvrage spécialisé Dictionary of Law de Peter Collin [CoLLIN]. Il est donc très rare dans la langue spécialisée, et totalement inconnu dans les dictionnaires généraux (autour de 50000 entrées). On ne le trouve pas attesté sur le moteur de recherche de la jurisprudence canadienne et le concept qu'il recouvre est exprimé par son synonyme creditor ${ }^{8}$. Il nous reste une hypothèse difficile à vérifier : celle de savoir si les utilisateurs de la forme debtee accentuent symétriquement debtor sur le suffixe.

debtor ['detə] noun [C]

- someone who owes money. [CALD]

Extrait du corpus : 
Debtor-Creditor Law: Practice and Doctrine.

Morguard investments ltd. c. De Savoye, 1990.

The insurance clause in the hypothecary loan contract contains all the elements of a contract of mandate, under which the hypothecary debtor has undertaken to keep the property subject to the hypothec insured. In accordance with that mandate, the hypothecary debtor took out an insurance policy containing a hypothecary clause. The wording of this clause indicates the existence of a second insurance contract between the hypothecary creditor and the insurer, a contract separate from the one purchased by the hypothecary debtor personally. Since the hypothecary creditor and not the debtor is the insured under this second insurance contract, indemnification of the hypothecary creditor for the loss caused by its debtor's intentional fault is not contrary to the prohibition of public order contained in art. 2563 C.C.L.C. Fault by the hypothecary debtor must be treated as fault by a third party.

Caisse populaire des deux rives v. Société mutuelle d'assurance contre l'incendie de la vallée du richelieu.

debtee [de'ti :] noun [C] SPECIALIZED (law)

- one to whom money is due (-> creditor). [CALD]

\subsubsection{Trustee et truster}

Nous retrouvons un problème converse avec trustee et *trustor, autre paire asymétrique puisque trustor n'existe pas 9 . En revanche, truster est attesté.

trustee [tr $\Lambda s^{\prime}$ ti:] noun [C]

- the one who holds a trust. [FREE]

- a person, often one of a group, who controls property and/or money for the benefit of another person or an organization. [CALD]

- person who has charge of money or property in trust or person who is responsible for a family trust. [CoLLIN]

Extrait du corpus :

The trustee sought to take possession of the garnisheed debt, but was refused by the House of Lords on the principle that the trustee "could not have it unless the bankrupt could himself have assigned it" (p.511). Accordingly, the trustee was not entitled to receive the debt free of the garnishee order "because the bankrupt could only have assigned it on November 12, subject to the garnishee order" (p. 511). Holt Cargo Systems Inc. v. ABC Containerline N.V. (Trustees of).

truster ['tr $\Lambda$ stə] noun [C] SPECIALIZED (law)

- someone who creates a trust -a convenient term used in the laws of Scotland, Bell's Com. 321, 6th ed.

Extrait du corpus :

[...] evidence that the offender, in committing the offence abused a position of trustor authority in relation to the victim [...]

Her Majesty the Queen v Darren Ervin.

Là encore, trustee n'est pas un mot dérivé d'un prédicat verbal : dans son sens spécialisé trust est un nom et cette catégorisation syntaxique prédomine linguistiquement dans la langue de spécialité. Dans trustee, comme dans debtor, un seul rôle est envisagé car la relation prédicative sous-jacente est monovalente (de type have) et il n'y a pas 
d'opposition polaire entre deux rôles. Reste à savoir pourquoi on a une dérivation en -ee dans un cas et en -or dans l'autre. Considérons les définitions :

- trustee : the one who holds a trust. [CALD] pas en paires. Pourquoi le dérivé en -ee n'est-il pas attesté ? Les règles particulières à la langue de spécialité que nous avons formulées précédemment s'appliquent-elles aux orphelins?

\subsection{Définitions de quelques items lexicaux orphelins}

adjudicator, dérivé de to adjudicate (to act as judge in a competition or argument, or to make a formal decision about something).

ex. : She acted as adjudicator in the dispute. [CALD]

aggressor [ə'gresə] n'est pas dérivé d'un verbe (puisque si aggression existe, le verbe *aggress n'est pas attesté).

- a person or country that starts an argument, fight or war by attacking first. [CALD]

contractor [kən'træktə] dérivé de to contract (to make a legal agreement with someone to do work or to have work done for you). 


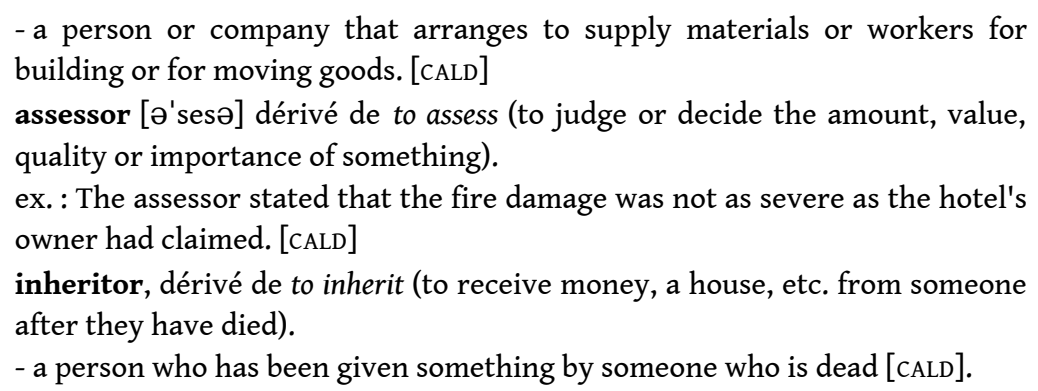

\subsection{Approche des orphelins du point de vue phonologique}

$$
\text { sommes intéressés à }
$$

\subsubsection{Nature de l'objet dans la relation prédicative}


un animé humain bénéficiaire, ne soit pas attesté. Avec invest, l'inanimé qui occupe la place d'objet, ne bénéficie de rien, et il est donc incompatible avec les traits sémantiques du suffixe -ee.

\subsubsection{Sémantisme du radical du dérivant / absence de relation prédicative}

Si nous étudions le mot proprietor, nous constatons qu'il n'est pas dérivé d'un verbe ( $a$ person who owns a particular type of business, especially a hotel, a shop or a company that makes newspapers [CALD]). En revanche, nous retrouvons avec cet exemple un prédicat verbal de type have $+\mathrm{N}$ puisque le verbe sous-jacent est to own. On ne possède pas un animé humain mais une chose, un objet ou bien un animé non humain (cf. possessor) : la dérivation en -ee est donc là encore bloquée puisqu'elle induirait un animé humain.

Examinons également le terme aggressor. Rappelons qu'aggressor ne dérive pas d'un prédicat verbal : en l'absence de relation prédicative, nous faisons l'hypothèse que ce sont des facteurs sémantiques qui excluent la dérivation en -ee. En effet, il semblerait qu' *aggressee ne soit pas attesté à cause du facteur sémantique : le suffixe -ee marque en effet le rôle thématique de bénéficiaire ; or, on a du mal à envisager d'être le "bénéficiaire » d'une agression (le sujet est affecté négativement, cf. tormentor). Dans ce cas, c'est donc le sémantisme même du radical aggress- qui empêche l'apparition d'un dérivé en -ee.

avançons également l'hypothèse que l'existence d'un suffixe unique est due au fait qu'aggressor est un terme relevant du droit pénal. Il n'implique par conséquent pas deux parties qui s'inscrivent dans une relation juridique spécifique devant la Cour (de type mortgagee / mortgagor ou bien covenantee / covenantor, termes qui eux relèvent du droit civil) mais une seule partie soumise à la justice. L'appartenance d'un terme à un domaine du droit plutôt qu'à un autre explique donc également l'existence d'un ou de plusieurs dérivants sur un même radical.

Les radicaux n'acceptent donc pas tous la dérivation avec le suffixe -ee. Il doit y avoir une adéquation entre les traits sémantiques du radical et ceux du suffixe pour que la dérivation fonctionne. Les différents blocages qui proscrivent le processus dérivationnel ont une double origine syntactico-sémantique : c'est, d'une part, le sémantisme de la racine des orphelins et, d'autre part, les propriétés distributionnelles et sémantiques relatives à l'argument objet qui interdisent le processus de dérivation avec le suffixe -ee.

Tableau 2. Tableau récapitulatif des orphelins en -or et des relations prédicatives sous-jacentes

\begin{tabular}{|l|l|l|}
\hline orphelins & structure argumentale sous-jacente & transitivité \\
\hline Abettor & [someone] to abet [someone] & T \\
\hline Adjudicator & [someone] to adjudicate on [something] & TI \\
\hline Aggressor & aggress- : non verbal & $*$ \\
\hline Arbitrator & [someone] to arbitrate [something] & T \\
\hline Assessor & [someone] to assess [something] & T \\
\hline Auditor & N et V [someone] to audit [something] & T \\
\hline
\end{tabular}




\begin{tabular}{|c|c|c|}
\hline Censor & cens : non verbal & * \\
\hline Conciliator & [someone] to conciliate between [something] & TI \\
\hline Contractor & [someone] to contract [something] & $\mathrm{T} / \mathrm{I}$ \\
\hline Contributor & [someone] to contribute to [something] & TI \\
\hline Councillor & council- : non verbal (nom) & * \\
\hline Creditor & [someone] to credit [something] & $\mathrm{T}$ \\
\hline Estimator & [someone] to estimate [something] & $\mathrm{T}$ \\
\hline Executor & [someone] to execute [something]-a will & $\mathrm{T}$ \\
\hline Governor & [someone] to govern [something] & $\mathrm{T} / \mathrm{I}$ \\
\hline Inheritor & [someone] to inherit [something] & $\mathrm{T} / \mathrm{I}$ \\
\hline Investor & [someone] to invest in [something] & TI \\
\hline Juror & jur : non verbal & * \\
\hline Legislator & [someone] to legislate for / against [something] & TI \\
\hline Moderator & [someone] to moderate [something] & $\mathrm{T} / \mathrm{I}$ \\
\hline Objector & [someone] to object to [something] & TI \\
\hline Perpetrator & [someone] to perpetrate against [someone] & TI \\
\hline Possessor & [someone] to possess [something] & $\mathrm{T}$ \\
\hline Proprietor & propriet- : non verbal & * \\
\hline Prosecutor & $\begin{array}{l}\text { [someone] to prosecute [s.o.] for [something] / complément non } \\
\text { bénéficiaire }\end{array}$ & TI \\
\hline Purveyor & [someone] to purvey [something] to [someone] & TI \\
\hline Solicitor & to solicit : sens différent & * \\
\hline Tormentor & [someone] to torment [someone] / complément non bénéficiaire & $\mathrm{T}$ \\
\hline
\end{tabular}

$\mathrm{T}$ : transitif direct ; $\mathrm{Tl}$ : transitif indirect ; $\mathrm{T} / \mathrm{I}$ : transitif ou intransitif.

\section{Cas spéciaux de mandator et de sponsor}

\subsection{Le cas de la triplette mandatee, mandator et mandatary}

mandator [mæn'deItə] / mandatary ['mændətəri] 
mandatee [mænde'ti:]

Paire alternante : 'Mandate N /10/, Man'date V /01/

Extrait du corpus :

As in the case of any mandate, the mandate between a manager and his client is imbued with the concept of trust, since the client places his trust in the manager - the mandatary - to manage his affairs. The very definition of mandate in art. 1701 C.C.L.C. conveys this concept. As one author has written, the word "confie" ("commits", in the English version) implies a degree of trust, on the part of the person granting the mandate, in the person receiving it. This element of trust explains, for instance, the mandator's authority to revoke the mandate at any time (art. 1756 C.C.L.C.; art. 2176 C.C.Q.). This spirit of trust is reflected in the weight of the obligations that rest on the manager, which will be heavier where the mandator is vulnerable, lacks specialized knowledge, is dependent on the mandatary, and where the mandate is important. The corresponding requirements of fair dealing, good faith and diligence on the part of the manager in relation to his client will thus be more stringent. 'Sansalone v. Wawanesa Mutual Insurance Co., SCC 25. File No 26708, 1999: October 14; 2000: May 3.

The strike fund, handled by the International Union, was established by the union, not the claimant, and the union was neither the agent nor the mandatary of the employees.

Hills v. Canada.

The Mortgagor as Mandator of the Mortgagee.

The mandator is bound in favour of third persons for all the acts of his mandatary, done in execution and within the powers of the mandate, except in the case provided for in article 1738 of this title, and the cases wherein by agreement or the usage of trade the latter alone is bound.

National Bank of Greece (Canada) v. Katsikonouris.

Dérivé non-contraint du verbe mandate /01/, qui est en paire accentuellement alternante avec le nom mandate /10/, le nom agentif mandator est accentué /010/. Quoique attesté dans l'OED, le mot mandatee (celui qui est mandaté, le mandataire) ne figure pas dans notre corpus, qui préfère exprimer le bénéficiaire du procès par le nom mandatary. Cette dérivation, qui semble spécifique à l'anglais juridique canadien, et importée directement par l'emprunt du français mandataire, a bloqué l'apparition dans le lexique de l'anglais du dérivé en -ee. Le suffixe -ary va donc se trouver en distribution complémentaire avec le suffixe -ee.

\title{
5.2. Le cas de sponsor
}

\author{
sponsor ['sppnsə]
}

Extrait du corpus :

\footnotetext{
Although none of these bills were passed, they were reflective of the public concern over this issue, since the sponsors of the bills represented different regions of the country, as well as the various political parties which have been represented in the House of Commons over the past 30 years.

Thomson Newspapers Co. v. Canada (Attorney General), 1998.

[...] or in any terrorist organization; or who were leaders of movements hostile to their government or sponsors of movements encouraging refugees not to return to their country of origin.

Pushpanathan v. Canada (Minister of Citizenship and Immigration).
} 
Sponsor est étymologiquement dérivé du verbe latin spondeo, spondere, sponsum. Ce radical n'a donné lieu a aucun verbe en anglais et c'est par conversion du sponsor latin (formé sur spons-, radical du supin) emprunté directement par l'anglais qu'on forme le verbe to sponsor dont le participe sponsored réfère au bénéficiaire. La terminaison -or de sponsor n'a pas la même transparence dérivationnelle que le -or de payor ni même de mandator. Sponsor n'entre pas dans une relation -or /-ee car il n'est pas analysé comme étant d'origine dérivationnelle. Le -ee ne peut pas être employé corrélativement à ce -or qui n'est pas un suffixe. La forme fléchie sponsored que l'on pourrait attendre dans des environnements similaires n'est attestée que très sporadiquement. C'est, d'une certaine manière, la flexion qui supplée à l'absence de dérivation : pour désigner le bénéficiaire on utilise le passif.

\section{Quelques considérations sur les suffixes -er et -ant : le cas de informer et de informant}

C'est la question de l'aspect des relations prédicatives qui se pose avec ces items, tous deux dérivés du radical inform. En effet, informer, qui correspond à un aspect itératif, réfère à l'informateur de la police, c'est-à-dire celui qui fournit de manière régulière des informations aux policiers. En revanche, l'aspect de la relation prédicative sous-jacente à informant est semelfactif : informant réfère à la personne qui fournit une seule information à un moment précis dans le cadre d'une procédure juridique. Le radical ne change pas mais les suffixes sont décisifs dans cet exemple car ils désignent deux référents complètement différents.

Gloses :

Informer: someone who regularly informs someone else (-er agent de l'itération).

Informant : someone who is in a position at one time to inform someone else.

Il découle un effet de sens péjoratif (aspect) = effet de sens (cas particulier).

Tableau 3. Tableau récapitulatif des paires et orphelins en -ee et en -or

\begin{tabular}{|l|l|l|l|}
\hline \multicolumn{2}{|l|}{ paires } & \multicolumn{2}{l|}{ orphelins } \\
\hline -or & $-e e$ & -or & -ee \\
\hline Assignor & Assignee & & \\
\hline Debtor & Debtee & & \\
\hline Mortgagor & Mortgagee & & \\
\hline Guarantor & Guarantee* & & \\
\hline Licensor & Licensee & & \\
\hline Lessor & Lessee & & \\
\hline
\end{tabular}




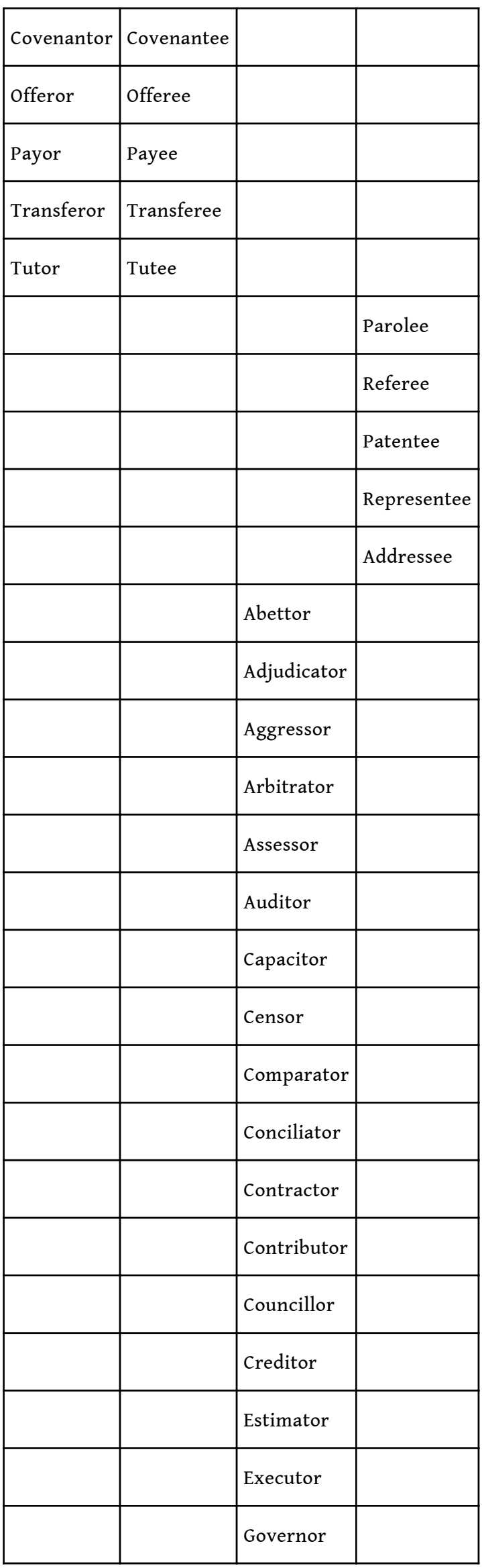




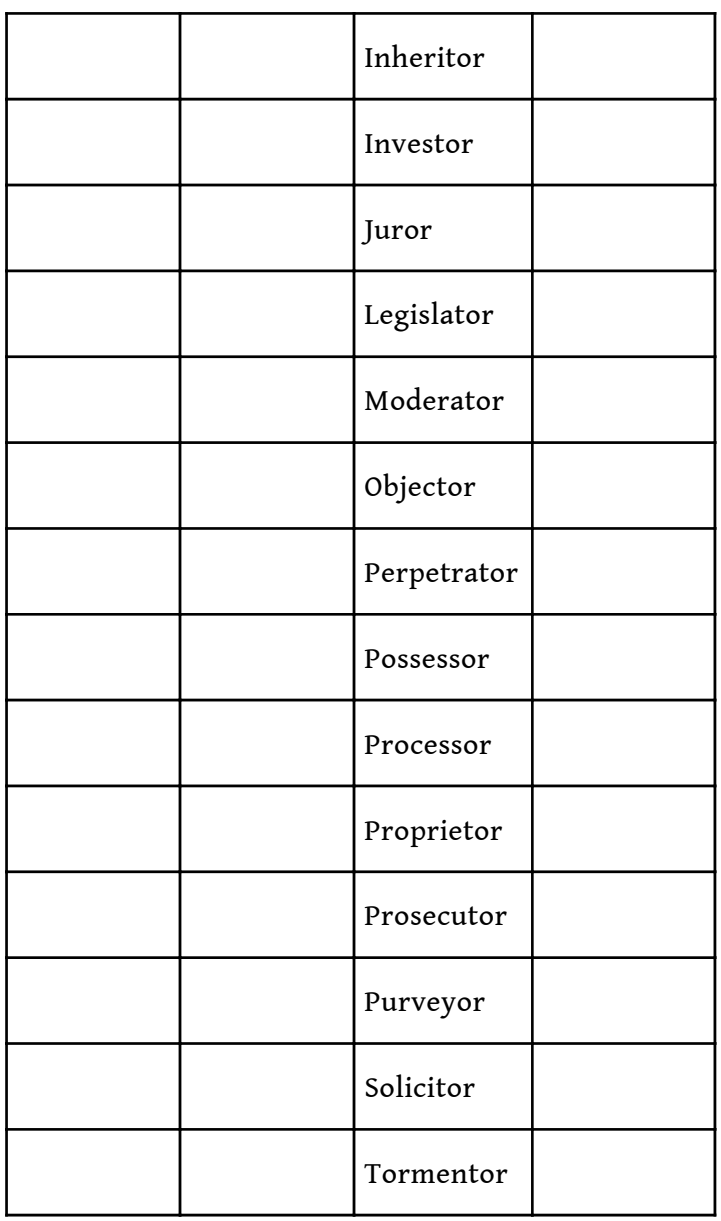

\section{Bilan des phénomènes linguistiques productifs en langue de spécialité}

On constate un effort d'harmonisation du lexique de la discipline par ses utilisateurs qui tentent de l'uniformiser grâce à un ensemble de processus internes récapitulés dans le tableau 4.

Tableau 4. phénomènes lexicologiques productifs en langue de spécialité

\begin{tabular}{|l|l|}
\hline $\begin{array}{l}\text { Regroupement des items lexicaux par paires avec variation du } \\
\text { suffixe dérivationnel (c'est généralement le prédicat sous-jacent } \\
\text { qui permet la paire) }\end{array}$ & $\begin{array}{l}\text { mortgagee / mortgagor } \\
\text { covenantee / covenantor } \\
\text { payee / payor } \\
\text { assignee / assignor }\end{array}$ \\
\hline Harmonisation lexicographique des paires & $\begin{array}{l}\text { payee / payor } \\
\text { payer (banal) payor } \\
\text { (spécialisé) }\end{array}$ \\
\hline
\end{tabular}




\begin{tabular}{|c|c|}
\hline $\begin{array}{l}\text { Harmonisation phonologique des paires - isomorphisme } \\
\text { accentuel et graphématique }\end{array}$ & 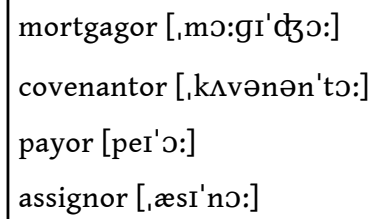 \\
\hline $\begin{array}{l}\text { Le cas des bases nominales: } \\
\text { Un dérivé prédomine (on n'a besoin que d'un seul). Reste à } \\
\text { choisir entre -ee et -or et ce sont alors des critères sémantiques } \\
\text { qui l'emportent }\end{array}$ & debtor \\
\hline $\begin{array}{l}\text { D'une manière générale, les suffixes marquent un rôle } \\
\text { thématique donné }\end{array}$ & $\begin{array}{l}-o r \rightarrow \text { agent } \\
-e e \rightarrow \text { bénéficiaire }\end{array}$ \\
\hline $\begin{array}{l}\text { Problème intralexicologique de la distinctivité terminologique : } \\
\text { il y a variation }{ }^{12} \text {, } \\
\text { - soit sur le morphème dérivationnel } \\
\text { - soit sur le lexème radical }\end{array}$ & $\begin{array}{l}\text { mortgagee / mortgagor } \\
\text { debtor / creditor }\end{array}$ \\
\hline $\begin{array}{l}\text { Les orphelins : } \\
\text { - manifestent une régularité accentuelle } \\
\text { - les propriétés distributionnelles des prédicats sont } \\
\text { déterminantes }\left({ }^{*} \text { investee }\right) \\
\text { - facteur sémantique (*aggressee) }\end{array}$ & $\begin{array}{l}\text { adjudicator } \\
\text { contractor } \\
\text { investor } \\
\text { proprietor } \\
\text { aggressor }\end{array}$ \\
\hline $\begin{array}{l}\text { On remarque une certaine hétérogénéité du lexique spécialisé } \\
\text { avec les cas spéciaux }\end{array}$ & $\begin{array}{l}\text { mandator /-ary / mandatee } \\
\text { sponsor }\end{array}$ \\
\hline $\begin{array}{l}\text { Relation juridique entre deux parties : } \\
\text { - Co-réciprocité ( } 1 \text { suffixe) } \\
\text { - Non-réciprocité ( } 2 \text { suffixes) }\end{array}$ & $\begin{array}{l}\text { contractor } \mathbf{1} \text { / contractor } 2 \\
\text { mortgagee / mortgagor, etc. }\end{array}$ \\
\hline $\begin{array}{l}\text { Les termes relèvent, } \\
\text { - soit du droit pénal (une partie : } 1 \text { suffixe) } \\
\text { - soit du droit civil (deux parties : } 2 \text { suffixes) }\end{array}$ & $\begin{array}{l}\text { agressor } \\
\text { covenantee / covenantor, } \\
\text { etc. }\end{array}$ \\
\hline
\end{tabular}

\section{Conclusion}

Sur le plan méthodologique, l'utilisation de corpus massifs contribue à affiner considérablement l'analyse. Sur le plan linguistique, notre étude micro-lexicale permet de dégager des hypothèses que d'autres études lexico-phonétiques pourront venir conforter.

La langue de spécialité juridique crée, en effet, au niveau lexicologique ses propres règles, fondées certes sur les règles communes de dérivation lexicologique et de correspondance entre graphie et phonie, mais, dans le sous-système observé, les relations juridiques s'expriment en relations prédicatives avec leurs contraintes propres pour imposer une 
désignation uniforme des participants à la relation. La motivation sémantique à forte cohésion interne, qui naît des paires lexicales examinées, en vient à battre en brèche l'arbitraire du signe par le développement d'un marquage phonologique sous forme de contrastes accentuels inédits. Ces marques de cohésion jouent en outre un rôle signalétique en ce qu'elles codent l'appartenance des termes qui les contiennent à un univers référentiel spécifiquement juridique.

\section{BIBLIOGRAPHIE}

\section{Références du corpus}

Décisions de la Cour suprême du Canada <http://www.lexum.umontreal.ca/>.

\section{Références bibliographiques}

Aurnague, M. \& M. Plénat. 1997. « Manifestations morphologiques de la relation d'attachement habituelle ». In Corbin D. et al. Mots possibles et mots existants, Actes du colloque de Villeneuve d'Ascq.

Deschamps, A., J-L. Duchet, J-M. Fournier \& M. O'Neil. 2003. English Phonology and Graphophonemics . Paris : Ophrys.

Duchet, J-L. 1994. Code de l'anglais oral. Paris : Ophrys.

Khalifa, J-C. 1999. La Syntaxe anglaise aux concours, théorie et pratique de l'énoncé complexe. Paris : A. Colin.

Kraif, O. 2001. «Constitution et exploitation de bi-textes pour l'aide à la traduction ». Thèse de doctorat en sciences du langage, Université de Nice-Sophia-Antipolis.

Paillard, M. 2000. Lexicologie contrastive anglais-français, formation des mots et construction du sens. Paris : Ophrys.

Paillard, M. \& F. Zumstein. 2000. « Aux frontières des morphèmes, aspect contrastif de la dynamique lexicale en anglais et en français ». Les Cahiers Forell $n^{\circ} 14$, Complexité syntaxique et sémantique, études de corpus, 187-208.

Tesnière, L. 1959. Éléments de syntaxe structurale. Paris : Klincksiek.

Villez, B. 1995. « Analyse morphologique des mots composés de l'anglais juridique ». ASp 7-10, 73-80.

\section{Dictionnaires}

Burke, J. 1976. Osborn's Concise Law Dictionary ( 6 e éd.). Londres : John Burke, Sweet \& Maxwell. [ OCLD]

Cambridge Advanced Learner's Dictionary (avec CD-ROM). 2003. Cambridge : Cambridge University Press.[CALD]

Dahl's Law Dictionary ( $2^{e}$ éd.). 1991. Paris : Dalloz.

Collin, P. 1993. Dictionary of Law ( $2^{e}$ éd.). Peter Collin Publishing. [collin]

Gifis, S. H. 1991. Law Dictionary (3e éd.). Barron's Legal Guides. [BARRON] 
The Free Dictionary. < http://www.thefreedictionary.com/>. [FREE]

Longman Dictionary of Contemporary English. [LDOCE]

Longman Pronouncing Dictionary (avec CD-ROM). [LPD]

Robert \& Collins senior, dictionnaire français-anglais, anglais-français ( $3^{\mathrm{e}}$ éd.). 2001.

\section{NOTES}

1. Cf. Duchet (1994).

2. Nous utilisons les conventions notationnelles héritées de Lionel Guierre, telles qu'elles sont définies dans Deschamps et al. (2003: 41) : chaque syllabe a un statut accentuel représentée par un chiffre: / $1 /$ pour l'accent primaire, /2/ pour l'accent principal et /0/ pour la syllabe inaccentuée.

3. Nous retrouvons le même phénomène avec la troncation de vegetable où veg est prononcé [vedz].

4. Cf. Paillard \& Zumstein au sujet de la variation $(2000: 202)$.

5. Nous reprenons ici, à la suite de J-C. Khalifa (1999: 42-43), la terminologie de L. Tesnière (1959). La valence permet de poser le verbe comme un noyau autour duquel gravitent un certain nombre d'arguments.

6. À la différence de guarantee où c'est l'objet qui est marqué du suffixe -ee (mais guarantor : a person who makes certain that something happens or that something is protected [CALD]).

7. Notons que même si la relation est réversible, le mortgagor reste fondamentalement l'agent déclencheur du processus de mortgaging : c'est lui qui se trouve à l'origine de l'initiative et de fait la relation reste orientée.

8. On trouve creditor utilisé en paire avec debtor dans la jurisprudence canadienne : par exemple «the subject provision should be limited to true debtor-creditor relationships » (Absolute Bailiffs Inc. v. The Queen, 2002-10-18).

9. Aucune attestation dans le corpus web de la jurisprudence canadienne.

10. Les auteurs de dictionnaires donnent priorité à la sémantique comme, par exemple, dans la paire debtor / creditor (someone who owes money / someone to whom money is owed: debtee executor, correlative to debtor). La définition utilise deux mots en -or ayant le même suffixe mais qui réfèrent à des rôles thématiques différents (on part de l'hypothèse que chaque suffixe devrait correspondre à un rôle différent).

11. Cf. Aunargue \& Plénat (1997 : 22-23).

12. Le contraste entre deux concepts complémentaires porte tantôt sur le lexème radical, tantôt sur le morphème dérivationnel. L'élément contrasté, dans chaque cas, porte l'accent lexical.

\section{RÉSUMÉS}

La recherche entreprise vise à présenter l'analyse de phénomènes lexicologiques inhérents à la langue de spécialité juridique. Elle se fonde sur un corpus constitué de cent trente arrêts de la Cour suprême du Canada. Il s'agit d'étudier les régularités et surtout de mettre au jour les particularités observables en anglais juridique, sur les plans prédicatif, lexicologique et 
phonologique. Sur la base d'exemples concrets rassemblés par concordancier et comparés aux données lexicographiques sur papier, sur CD-ROM et en ligne, nous tenterons de conforter l'hypothèse de l'existence de règles lexicologiques particulières à la langue de spécialité, notamment canadienne. Une micro-analyse des dérivés en -ee, -or, -er, -ary servira de test à cette hypothèse et aux analyses complémentaires qu'appelle sa confrontation aux données.

This study aims at analysing the various morphological and phonological processes that are specific to legal English as a specialized language. The project is based on the detailed analysis of a computer-readable corpus composed of one hundred and thirty decisions of the Supreme Court of Canada. Specific facts and regular patterns are observed in the legal language in terms of argument structure, word formation and pronunciation. The words under scrutiny have been gathered with a concordancer and are systematically compared to lexicographical material on paper, CD-ROM and online. The study sets out to demonstrate that there are some specific morphological rules that apply in legal English, especially in Canada. The detailed study focuses on suffix formations in -ee, -or, -er, -ary and aims at testing the above hypothesis and complementing it through further analysis.

\section{INDEX}

Mots-clés : affixation dérivationnelle, concordancier, corpus parallèle, lexicologie, morphologie lexicale, sémantique lexicale

Keywords : concordancing, derivational morphology, lexical semantics, parallel corpus, word formation

\section{AUTEURS}

\section{JEAN-LOUIS DUCHET}

Jean-Louis Duchet est professeur à l'Université de Poitiers où il dirige la Faculté des Lettres \& des Langues. Il appartient à l'EA1226 FORELL (MSHS-CNRS \& Université de Poitiers). Ses recherches portent principalement sur la linguistique de corpus appliquée aux documents oraux, aux états anciens de la langue (notamment par le biais de la numérisation de dictionnaires anciens) et sur la langue de spécialité juridique. Il co-préside avec Alain Cazade l'atelier Nouvelles technologies pour l'enseignement et la recherche aux congrès de la SAES. jean-louis.duchet@univ-poitiers.fr

\section{OLIVIER CHAULET}

Olivier Chaulet, professeur certifié d'anglais, est jeune chercheur de l'EA1226 FORELL. Il a entamé des recherches en lexicologie de l'anglais juridique. Il a réalisé un site web pour la présentation de corpus bilingues alignés comme outil pour la traduction et la recherche en syntaxe et en lexicologie contrastives du français et de l'anglais <http://cabal.rezo.net>. olivier.chaulet@univpoitiers.fr 